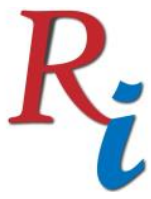

Asia Proceedings of Social Sciences

(APSS)

www.readersinsight.net/APSS

\title{
MODERATING ROLE OF CORRUPTION CONTROL ON FIRM \\ LEVEL DETERMINANTS OF CORPORATE SUSTAINABILITY \\ DISCLOSURE COMPLIANCE IN NIGERIA
}

\section{Mohammed Sabo Bello *}

School of Business and Economics, Department of Accounting and Finance,

Universiti Putra Malaysia, Serdang,

Malaysia.

Yobe State University, PMB 1144, Damaturu, Yobe State,

Nigeria.

msabobello@yahoo.com

\section{Ridzwana Mohd Said}

School of Business and Economics, Department of Accounting and Finance, Universiti Putra Malaysia, Serdang,

Malaysia.

ridzwana@upm.edu.my

\section{Jalila Johari}

School of Business and Economics, Department of Accounting and Finance, Universiti Putra Malaysia, Serdang,

Malaysia.

jjohari@upm.edu.my

\section{Fakarudin Kamarudin}

School of Business and Economics, Department of Accounting and Finance, Universiti Putra Malaysia, Serdang,

Malaysia.

fakarudin@upm.edu.my

*Corrosponding author's Email: msabobello@yahoo.com

Peer-review under responsibility of 4th Asia International Multidisciplinary Conference 2020 Scientific Committee

http://connectingasia.org/scientific-committee/

(C) 2020 Published by Readers Insight Publisher,

lat 306 Savoy Residencia, Block 3 F11/1,44000 Islamabad. Pakistan,

editor@readersinsight.net

This is an open access article under the CC BY-NC-ND license (http://creativecommons.org/licenses/by-nc-nd/4.0/). 


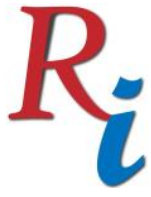

\section{Asia Proceedings of Social Sciences (APSS) \\ www.readersinsight.net/APSS}

\section{A b s t r a c t}

This paper explores the moderating effect of corruption control in strengthening the influence of firm attributes on corporate sustainability disclosure compliance in Nigeria. The study focuses on the existing discussion on mandatory disclosure compliance with corporate governance code. The extent of disclosure compliance is measured using a total unweighted disclosure index, developed from a panel dataset of 118 companies listed in the Nigerian capital market. The companies were selected using a proportionate stratified sampling technique. The dataset for the period of 2011 to 2017 were first analyzed by static panel regression analysis using pooled Ordinary Least Square (OLS), Fixed Effect (FE), and Random Effect (RE) models. The regression models were subjected to further robustness checks under dynamic GMM panel regression analysis, to test for possible endogeneity. The findings revealed significant moderating effect of corruption control, evidenced from the interaction of corruption control with selected firm attributes, namely; industry type, leverage and taxation. The research contributes to the existing literature, as it establishes the importance of control of corruption as an additional factor of corporate sustainability disclosure compliance within the context of Nigeria.

Keywords: Environmental and Social Information; Corporate Governance; Compliance; Corruption Control

\section{Research Objectives}

Corruption has been considered as a global issue over the last three decades (UN, 2017). It is also considered to be a challenge to achieve the sustainable development goals (SDG) of ending extreme poverty by the year 2030 (World Bank, 2018). Corrupt practices constitute a critical setback in the growth of businesses operating in developing economies (Issa \& Alleyne, 2018).

Within the preface of the 2003 corporate governance (CG) code issued by the Securities and Exchange Commission (SEC), the commissin considers the need to align the content of the code which led to the issuance of the 2011 CG code, which was further replaced by the 2016 $\mathrm{CG}$ code. Thus, to ensure improved compliance with the CG code, the findings from this study will serve as a guide when enacting new codes or modifying existing guidelines.

The current study is further motivated by the prevailing rise in the level of corruption across the globe, but particularly in Nigeria, where the phenomenon is considered as a pressing issue. The Business Anti-Corruption Portal (2018) report shows that the issue of corruption is still Nigeria's greatest obstacle to business. Therefore, this study aims to examine the moderating effect of corruption control in strengthening the influence of firm attributes, towards Corporate Sustainability Disclosure Compliance (CSDC). 


\section{Methodology}

The study is based a deductive approach using quantitative methodological choice. Population comprises of 170 listed companies, list obtained from the Nigerian Stock Exchange official website. The sample size consist of 118 listed companies in Nigeria selected across different industries using the proportionate stratified sampling technique. The firm level data extracted from annual reports of sampled for seven year period (2011 to 2017).

Static Regression Models:

Below are the model used to test the moderating influence of corruption, the interaction variables $(\beta 8)$ is used to test the moderating effects corruption control.

lcsdcit $=\alpha 0+\beta 1$ lliqdit $+\beta 2$ indtit $+\beta 3$ lleveit $+\beta 4$ ltaxait $+\beta 5$ lfsizeit $+\beta 6$ lfageit $+\beta 7$ lccont $+\lambda \mathrm{i}+$ cit

lcsdcit $=\alpha 0+\beta 1$ lliqdit $+\beta 2$ indtit $+\beta 3$ lleveit $+\beta 4$ ltaxait $+\beta 5$ lfsizeit $+\beta 6$ lfageit $+\beta 7$ lccont $+\beta 8$ (lliqdit x lccont) $+\lambda i+\varepsilon i t$

lcsdcit $=\alpha 0+\beta 1$ lliqdit $+\beta 2$ indtit $+\beta 3$ lleveit $+\beta 4$ ltaxait $+\beta 5$ lfsizeit $+\beta 6$ lfageit $+\beta 7$ lccont $+\beta 8$ (indtit $\mathrm{x}$ lccont) $+\lambda \mathrm{i}+\varepsilon \mathrm{it}$

lcsdcit $=\alpha 0+\beta 1$ lliqdit $+\beta 2$ indtit $+\beta 3$ lleveit $+\beta 4$ ltaxait $+\beta 5$ lfsizeit $+\beta 6$ lfageit $+\beta 7$ lccont $+\beta 8$ (lleveit $\mathrm{x}$ lccont $)+\lambda \mathrm{i}+\varepsilon \mathrm{it}$

lcsdcit $=\alpha 0+\beta 1$ lliqdit $+\beta 2$ indtit $+\beta 3$ lleveit $+\beta 4$ ltaxait $+\beta 5$ lfsizeit $+\beta 6$ lfageit $+\beta 7$ lccont $+\beta 8$ (ltaxait $\mathrm{x}$ lccont) $+\lambda \mathrm{i}+\varepsilon \mathrm{it}$

Further check was conducted using the two step system GMM for the possible endogeneity problem in the above models, by introducing the lagged dependent variable $\left(\operatorname{Llcsdc}_{t-1}\right)$ among the regressor in models G1 to G5.

\section{Results}

Results from the static model shows three interactions variables (indt*lccon, lleve*lccon and ltaxa*lccon) have statistically significant moderating effect of corruption control on the corporate sustainability disclosure compliance (lcsdc). Conversely, Interaction of liquidity and corruption control (lliqd*lccon) appears not to be statistically significant. Findings from the robustness check under the dynamic GMM regression analysis models shows two significant interactions (indt*lccon and lleve*lccon) as present in tables 1 and 2 below 


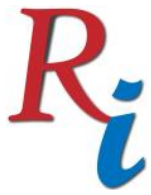

\section{Asia Proceedings of Social Sciences}

(APSS)

www.readersinsight.net/APSS

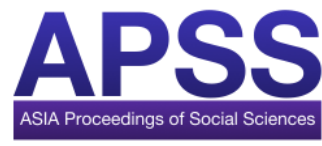

Table 1: Static Regression Results for the Moderating Effect of Corruption Control

\begin{tabular}{llllll}
\hline DV: lcsdc & Model S1 & Model S2 & Model S3 & Model S3 & Model S3 \\
\hline Variables: & $(\mathbf{R E})$ & $\mathbf{( R E )}$ & $\mathbf{( R E )}$ & $\mathbf{( R E )}$ & $\mathbf{( R E )}$ \\
\hline lccon & 0.00585 & 0.0692 & 0.0479 & 0.0207 & 0.0550 \\
$\begin{array}{l}\text { lliqd*Iccon } \\
\text { indt*lccon }\end{array}$ & & 0.00533 & & & \\
$\begin{array}{l}\text { lleve*Iccon } \\
\text { ltaxa*lccon }\end{array}$ & & & $\mathbf{0 . 0 3 4 4 * * *}$ & & \\
\hline
\end{tabular}

Table 2: Robustness Check: GMM Results for the moderating effect of Corruption Control

\begin{tabular}{lccccc}
\hline DV: lcsdc & $\begin{array}{c}\text { Model G1 } \\
\text { Variables: }\end{array}$ & $\begin{array}{c}\text { Model G2 } \\
(\mathbf{G M M})\end{array}$ & $\begin{array}{c}\text { Model G3 } \\
(\mathbf{G M M})\end{array}$ & $\begin{array}{c}\text { Model G4 } \\
(\mathbf{G M M})\end{array}$ & $\begin{array}{c}\text { Model G5 } \\
(\mathbf{G M M})\end{array}$ \\
\hline L.lcsdc & $0.182 * * *$ & $0.170 * * *$ & $0.162 * * *$ & $0.173 * * *$ & $0.167 * * *$ \\
lccon & -0.00326 & -0.0136 & -0.0724 & -0.0919 & -0.0687 \\
lliqd*lccon & & 0.00859 & & & \\
indt*lccon & & & $\mathbf{0 . 0 3 0 4 * *}$ & & \\
lleve*lccon & & & & $\mathbf{0 . 0 2 6 9 * * *}$ & \\
ltaxa*lccon & & & & $\mathbf{- 0 . 0 0 4 9 5}$ \\
\hline
\end{tabular}

\section{Findings}

Nigeria is currently intensifying the fight against corruption with special emphasis on its public sector. However, knowledge of the effect of corruption control on corporate sustainability disclosure has not been rigorously ascertained by prior studies. The current fight against corruption couple with focus on environmentally sensitive firms and improved source of funding shall improve the level of corporate sustainability disclosure compliance in Nigeria. Finally, based on our findings we recommend that, regulatory and policy makers must enact policies targeted toward intensifying fight against corruption in both public and private sectors in Nigeria.

\section{References}

Business Anti-Corruption Portal BAP. (2018). Nigeria Corruption Report. Retrieved November 19, 2017, from GAN Integrity Inc. website: https://www.business-anticorruption.com/country-profiles/nigeria/

Issa, A., \& Alleyne, A. (2018). Corporate disclosure on anti-corruption practice. Journal of Financial Crime, 25(4), 1077-1093. https://doi.org/10.1108/JFC-05-2017-0045 


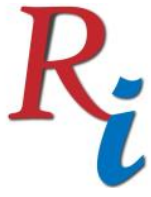

\section{Asia Proceedings of Social Sciences}

(APSS)

www.readersinsight.net/APSS

United Nations. (2017). Corruption in Nigeria Bribery: public experience and response. Retrieved from https://www.unodc.org/documents/data-and-analysis/Crimestatistics/Nigeria/Corruption_Nigeria_2017_07_31_web.pdf

World Bank. (2018). Combating corruption. Retrieved November 20, 2018, from http://www.worldbank.org/en/topic/governance/brief/anti-corruption 